\title{
ANALISIS PENGARUH PENGELUARAN PEMERINTAH TERHADAP PERTUMBUHAN EKONOMI DAN INDEKS PEMBANGUNAN MANUSIA DI INDONESIA
}

\author{
Ginanjar Aji Nugroho \\ Program Magister Ilmu Ekonomi \\ Pascasarjana Fakultas Ekonomi dan Bisnis Universitas Brawijaya \\ Alamat Korespondensi: ginanjar.ajinugroho@gmail.com
}

\section{INFORMASI ARTIKEL}

Diterima Pertama

23 Mei 2016

Dinyatakan Diterima

15 Juli 2016

KATA KUNCI:

Fiscal Policy, Economic Development, Regional Economy, Government Expenditure, Economic Growth, Human Development Index.

KLASIFIKASI JEL:

E62, H3, 011, 015, R5

\begin{abstract}
ABSTRAK
The puposes of this study are (1) to analyze the effects of government expenditures on education, health and infrastructure sectors toward economic growth and human development index in Indonesia, (2) to investigate the impacts of economic growth on human dvelopment index, (3) and to examine the effects of government expenditures on education, health and infrastructure sectors toward human development index both directly and through the economic growth. The study used samples from twenty provinces, which were selected using simple random sampling, divided into two groups; the first group comprised higher HDI provinces; the second group consisted of lower HDI provinces. To examine the model, the study applied path analysis method. The mean test was also applied to determine whether there were statistical average differences between the two groups. The results of this study show different responds between the higher HDI provinces and lower HDI provinces. The higher HDI provinces show that government expenditures on health and infrastructure have positive and significant impacts on human development index through economic growth indirectly; on the other hand, the lower HDI provinces show that only expenditure on education gives positive and significant impacts on human development index. Meanwhile, the economic growth shows positive and significant impacts on human development index in both higher HDI and lower HDI provinces.
\end{abstract}

Penelitian ini bertujuan untuk: (1).Mengetahui pengaruh pengeluaran pemerintah pada sektor pendidikan, kesehatan dan infrastruktur terhadap pertumbuhan ekonomi dan indeks pembangunan manusia (IPM) di Indonesia, (2).Mengetahui pengaruh pertumbuhan ekonomi terhadap IPM, dan (3).Mengetahui pengaruh pengeluaran pemerintah pada sektor pendidikan, kesehatan dan infrastruktur terhadap IPM, baik secara langsung maupun melalui pertumbuhan ekonomi. Penelitian ini menggunakan sampel dua puluh provinsi yang dipilih dengan teknik simple random sampling yang kemudian dibagi kedalam dua kelompok, yaitu kelompok daerah dengan angka IPM tinggi dan kelompok daerah dengan angka IPM rendah. Metode yang digunakan dalam penelitian ini adalah analisis jalur. Sebagai pendukung, juga dilakukan uji beda rata-rata untuk mengetahui ada tidaknya perbedaan rata-rata secara statistik terhadap dua kelompok tersebut. Hasil estimasi menunjukkan bahwa terdapat perbedaan respon diantara dua kelompok daerah tersebut. Pada kelompok daerah dengan angka IPM tinggi, terlihat bahwa pengeluaran kesehatan dan infrastruktur mempunyai pengaruh positif dan signifikan terhadap IPM melalui pertumbuhan ekonomi, sedangkan pada kelompok daerah dengan angka IPM rendah terlihat bahwa hanya pengeluaran pendidikan yang mempunyai pengaruh positif dan signifikan terhadap angka IPM. Adapun pertumbuhan ekonomi, terlihat menunjukkan pengaruh yang positif dan signifikan terhadap IPM. Hal ini terjadi pada kedua kelompok daerah, baik kelompok daerah dengan IPM tinggi maupun IPM rendah. 


\section{PENDAHULUAN}

\subsection{Latar Belakang}

Pembangunan manusia menempatkan manusia sebagai tujuan pembangunan, dan bukan sema-mata sebagai alat pembangunan. Menurut Ginting et al (2008) dalam Setyowati dan Suparwati (2012), sumber daya pembangunan tidak lagi meletakkan prioritas pada kekuatan sumber daya alam, melainkan pada kekuatan sumber daya manusia. ${ }^{1}$ Dengan demikian, diperlukan strategi pembangunan yang menitikberatkan pada pembangunan sumber daya manusia. Pembangunan sumber daya manusia yang berhasil, akan mendukung terciptanya pertumbuhan ekonomi. Salah satu cara untuk mengukur standar pembangunan manusia yang ditetapkan oleh Perserikatan Bangsa-Bangsa (PBB) adalah melalui Human Development Index (HDI) atau Indeks Pembangunan Manusia (IPM) (BPS, 2009).

Indeks Pembangunan Manusia (IPM) sendiri dapat digunakan untuk mengklasifikasikan apakah sebuah negara termasuk dalam kategori negara maju, negara berkembang atau negara terbelakang, dan juga untuk mengukur pengaruh kebijakan ekonomi terhadap kualitas hidup. IPM adalah indeks komposit untuk mengukur pencapaian kualitas pembangunan manusia untuk dapat hidup secara lebih berkualitas, baik dari aspek kesehatan, pendidikan, maupun aspek ekonomi. ${ }^{2}$ Kondisi saat ini, catatan angka IPM antarprovinsi masih menunjukkan perbedaan yang cukup mencolok. Hal ini menimbulkan gap antara daerah dengan IPM tinggi dan daerah dengan IPM rendah. Pada tahun 2013, angka IPM tertinggi dimiliki oleh provinsi DKI Jakarta dengan angka sebesar 78,59 sedangkan angka terendah tercatat di provinsi Papua dengan angka sebesar 66,25. Hal ini dapat ditunjukkan pada gambar berikut:

1 Lilis Setyowati dan Yohana Kus Suparwati, "Pengaruh Pertumbuhan Ekonomi, DAU, DAK, PAD Terhadap Indeks Pembangunan Manusia dengan Pengalokasian Anggaran Belanja Modal Sebagai Variabel Intervening (Studi Empiris Pada Pemerintah Kabupaten dan Kota Se-Jawa Tengah)", Prestasi, 2012, Vol. 9, No. 1.

2 Fhino Andrea Christy dan Priyo Hari Adi, Hubungan antara Dana Alokasi Umum, Belanja Modal dan Kualitas Pembangunan Manusia, The $3^{\text {rd }}$ National Conference UKWMS, 2009.
Gambar 1. Angka IPM Antarprovinsi tahun 2013

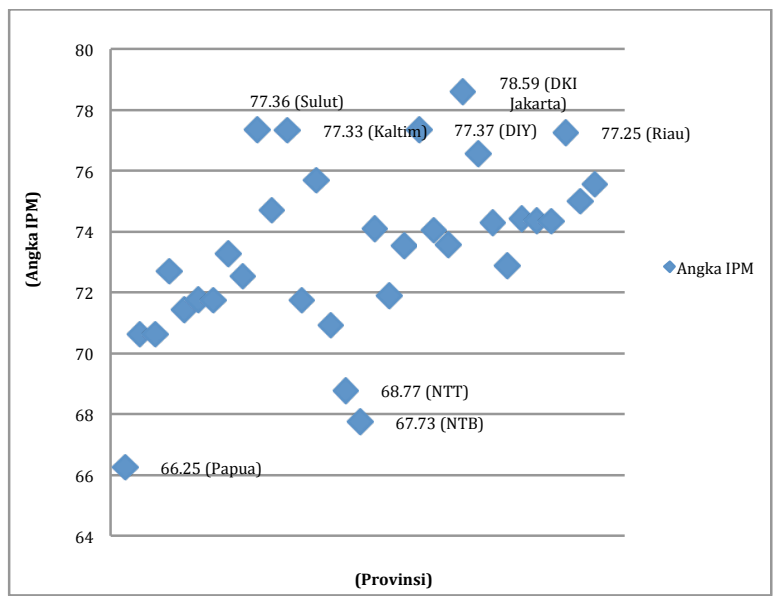

Sumber: BPS (data diolah)

Provinsi DKI Jakarta mempunyai peningkatan yang dinamis, dimulai pada tahun 2009 angka IPM tercatat sebesar 77,36 kemudian meningkat menjadi sebesar 77,60 pada tahun 2010 dan secara dinamis meningkat pada tahun-tahun selanjutnya dan tercatat sebesar 78,59 pada tahun 2013. Lima provinsi dalam catatan tertinggi angka IPM dari tahun ke tahun selalu dimiliki oleh provinsiprovinsi seperti: DKI Jakarta, Daerah Istimewa Yogyakarta (DIY), Sulawesi Utara, Kalimantan Timur dan Riau dengan angka IPM berada pada kisaran 77,00 sampai dengan 79,00. Sedangkan data lima terendah IPM dari tahun ke tahun selama masa observasi tahun 2009-2013 adalah sebagian provinsi yang berada pada wilayah timur Indonesia yaitu Maluku Utara, Papua Barat, Nusa Tenggara Timur (NTT), Nusa Tenggara Barat (NTB) dan Papua dengan kisaran angka IPM antara 66,00 sampai dengan 69,00.

Secara konseptual, kinerja ekonomi suatu provinsi dapat dilihat dari jumlah Produk Domestik Regional Bruto (PDRB). Dalam era otonomi daerah, pertumbuhan ekonomi suatu daerah dipengaruhi oleh pengeluaran pemerintah. Pengalokasian belanja pemerintah pada sektor pendidikan dan kesehatan merupakan usaha nyata dan bentuk perhatian pemerintah daerah dalam rangka mencapai tujuan pembangunan serta mendukung terciptanya peningkatan kualitas manusia. Komposisi pengeluaran pemerintah, dapat dilihat pada gambar berikut: 


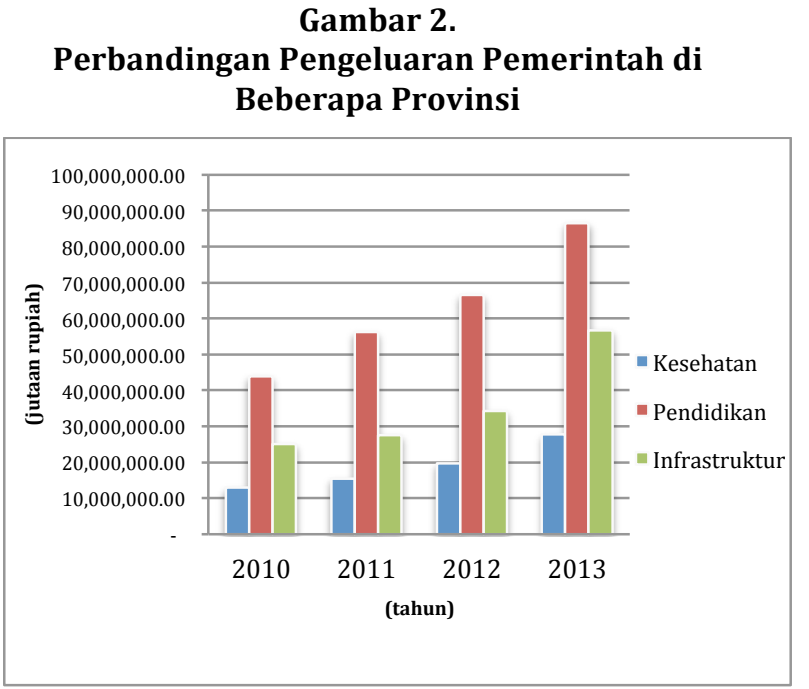

Sumber: www.djpk.kemenkeu.go.id (data diolah)

Pengeluaran infrastruktur terlihat mempunyai kecenderungan yang meningkat dari tahun ke tahun. Hal ini menunjukkan bahwa kebutuhan akan pembangunan sarana dan prasarana tersebar merata di hampir semua daerah. Hal ini juga menunjukkan besarnya peranan pengeluaran infrastruktur sebagai komponen penting dalam penyelenggaraan proses pembangunan. Namun, secara implementasi, kebutuhan akan pembangunan fasilitas infrastruktur pendukung tidak diiringi dengan penyediaan anggaran. Hal ini terlihat dari porsi alokasi untuk pengeluaran infrastruktur yang masih lebih kecil dari porsi pengeluaran kesehatan dan pendidikan.

Pengeluaran kesehatan terlihat lebih kecil apabila dibandingkan dengan pengeluaran pendidikan maupun infrastruktur. Dari tahun ke tahun, realisasi di sektor kesehatan terlihat lebih kecil daripada realisasi di sektor pendidikan dan infrastruktur. Komposisi pengeluaran yang seperti ini terlihat pada sebagian besar daerah provinsi. Hal ini tentunya mengundang perhatian pemerintah untuk lebih memperhatikan pola dan alokasi pengeluaran pemerintah untuk mencapai tujuan pembangunan yang lebih merata.

Berdasarkan uraian latar belakang permasalahan tersebut di atas, maka penelitian ini mempunyai beberapa tujuan yang ingin dicapai, antara lain: 1). Untuk mengetahui pengaruh pengeluaran pemerintah terhadap pertumbuhan ekonomi untuk daerah dengan angka IPM tinggi dan daerah angka IPM rendah; 2). Untuk mengetahui pengaruh pertumbuhan ekonomi terhadap IPM untuk daerah dengan angka IPM tinggi dan daerah angka IPM rendah; 3). Untuk mengetahui pengaruh pengeluaran pemerintah terhadap IPM untuk daerah dengan angka IPM tinggi dan daerah dengan angka IPM rendah, serta untuk mengetahui pengaruh pengeluaran pemerintah terhadap IPM melalui pertumbuhan ekonomi untuk daerah dengan angka IPM tinggi dan daerah dengan angka IPM rendah.

\subsubsection{Hipotesis Penelitian}

Hipotesis merupakan jawaban sementara terhadap rumusan masalah penelitian, karena jawaban yang diberikan baru berdasarkan pada teori-teori yang relevan, belum didasarkan pada fakta-fakta empiris yang diperoleh melalui pengumpulan data. Hipotesis dapat juga dipandang sebagai kesimpulan yang sifatnya sangat sementara. Hipotesis yang diajukan dalam penelitian ini adalah:

1. Diduga pengeluaran pemerintah berpengaruh positif dan signifikan terhadap pertumbuhan ekonomi untuk daerah yang IPM-nya tinggi dan daerah yang IPM-nya rendah di Indonesia pada periode 2009-2013.

2. Diduga pertumbuhan ekonomi berpengaruh positif dan signifikan terhadap IPM untuk daerah yang IPM-nya tinggi dan daerah yang IPM-nya rendah di Indonesia pada periode 2009-2013.

3. Diduga pengeluaran pemerintah berpengaruh positif dan signifikan terhadap IPM baik secara langsung maupun melalui pertumbuhan ekonomi untuk daerah yang IPM-nya tinggi dan daerah yang IPM-nya rendah di Indonesia pada periode 2009-2013.

\section{KERANGKA TEORI DAN PENGEMBA- NGAN HIPOTESIS}

\subsection{Teori Desentralisasi}

Terdapat dua perspektif dalam kajian tentang fiscal federalism yaitu the traditional theories dan the new perspective theories.

\subsubsection{The Traditional Theories (First Generation Theories)}

Teori ini menekankan tentang manfaat atau keuntungan alokatif yang diperoleh dengan adanya desentralisasi fiskal. Maksud dari keuntungan alokatif adalah bahwa dengan adanya fiscal federalism, pemerintah daerah memperoleh kemudahan dalam mendapatkan informasi dari masyarakat. Ada 2 (dua) hal yang mendasari adanya keuntungan alokatif, seperti yang dikemukakan oleh Hayek (1945) dan Tiebout (1956). Yang pertama adalah pendapat Hayek (1945) tentang penggunaan "knowledge in society". Menurut Hayek (1945), proses pengambilan keputusan dalam konteks desentralisasi akan lebih mudah dilaksanakan disebabkan dengan adanya penggunaan informasi yang efisien. ${ }^{3}$ Informasi yang efisien dapat diperoleh

3 F. A. Hayek, "The Use of Knowledge in Society", American Economic Review, 1945, Vol. XXXV, hlm. 519-530. 
disebabkan oleh posisi pemerintah daerah yang lebih dekat dengan masyarakat. Keadaan seperti inilah yang kemudian mendukung terciptanya allocative efficiency (Khusaini, 2006).

Manfaat kedua dari adanya desentralisasi dikemukakan oleh Tiebout (1956) yang menyoroti tentang adanya ruang atau kesempatan bagi pemerintah daerah untuk saling berkompetisi. ${ }^{4}$ Selain kedua manfaat yang telah disebutkan sebelumnya, desentralisasi juga memungkinkan adanya local experiment bagi pemerintah daerah untuk mempelajari pengalaman daerah lain. Pemerintah daerah dapat mencontoh keberhasilan daerah lain dan sekaligus belajar dari kegagalan daerah lain pula. Local experiment seperti ini mengurangi risiko kegagalan sistem yang bersifat sentralistik.

\subsubsection{New Perspective Theories (Second Generation Theories)}

Pada dasarnya, new perspective theories menitikberatkan kepada dua mekanisme dalam rangka menciptakan keselarasan antara kepentingan pemerintah daerah dengan kemakmuran ekonomi, interaksi horizontal antar pemerintah daerah dan interaksi vertikal antar level pemerintahan. Pertama, pada situasi pasar dengan mobilitas tinggi, kompetisi antar pemerintah daerah menjadi instrumen penting dalam rangka penyediaan barang dan jasa publik. Strategi dan persaingan antar pemerintah daerah dalam memberikan pelayanannya kepada pasar akan mampu mendorong pergerakan perekonomian yang pada akhirnya akan mendorong pertumbuhan ekonomi. Namun sebaliknya, apabila peraturan pemerintah dan jasa publik yang disediakan tidak kondusif untuk pasar dan masyarakat, maka hal ini akan memunculkan potensi mobilitas faktor produksi ke daerah lain yang pada akhirnya akan memberikan dampak negatif terhadap pertumbuhan ekonomi daerah dan kesejahteraan masyarakat lokal. Sedangkan poin kedua yaitu, hubungan antara penerimaan dan pengeluaran daerah yang begitu erat juga dapat menjadi insentif bagi pemerintah daerah dalam rangka meningkatkan kondisi perekonomiannya.

\subsection{Pengeluaran Pemerintah di Sektor Pendidikan}

Pendidikan merupakan tujuan pembangunan yang sangat mendasar. Adapun dikatakan mendasar karena masing-masing mempunyai arti yang penting. Pendidikan merupakan bagian penting

4 Charles M. Tiebout, "A Pure Theory of Local Expenditure”, Journal of Political Economy, 1956, Vol. 64, hlm. 416-424. dalam pencapaian kapabilitas manusia, yang juga bersifat esensial bagi kehidupan masyarakat. Sedangkan kesehatan merupakan bagian penting dalam upaya pencapaian kesejahteraan serta merupakan bagian fundamental dalam peningkatan kapabilitas manusia (Todaro dan Smith, 2011).

Modal manusia merupakan investasi produktif terhadap orang-orang; mencakup pengetahuan, keterampilan, kemampuan dan gagasan. Hal ini merupakan komponen penting dalam rangka mendukung program pembangunan, terutama pembangunan ekonomi dengan skema benefit spillover. Maka dari itu, modal manusia harus mendapat perhatian langsung dan khusus karena arti pentingnya, terlebih lagi dalam keadaan perekonomian yang tumbuh dengan pesat. Besarnya pengeluaran pemerintah dalam sektor pendidikan akan menentukan seberapa besar pencapaian hasil pembangunannya. Lin (1998), dalam sebuah studinya mengenai keterkaitan antara pengeluaran pemerintah di sektor pendidikan dengan modal manusia, mengungkapkan bahwa meningkatnya pengeluaran pemerintah di sektor pendidikan cenderung meningkatkan ketersediaan modal manusia.

\subsection{Pengeluaran Pemerintah di Sektor Kesehatan}

Kesehatan menjadi isu sentral dalam pembahasan pembangunan, khususnya pembangunan ekonomi. Kesehatan juga menjadi sektor yang tidak kalah penting dengan sektor pendidikan. Dalam posisinya sebagai tujuan pembangunan yang paling mendasar, kesehatan mempunyai arti yang sangat penting bagi kesejahteraan. Bersama- sama dengan pendidikan, dua hal ini adalah hal fundamental bagi peningkatan kapabilitas manusia sebagai inti makna pembangunan.

Aisa dan Pueyo (2006) mengungkapkan dalam penelitiannya bahwa pengeluaran pemerintah untuk kesehatan mempunyai pengaruh positif terhadap harapan hidup dan pertumbuhan ekonomi, yang didukung dengan pengeluaran yang cukup. Hal ini terutama terjadi pada negara- negara berkembang. Lebih lanjut lagi dikatakan bahwa semakin tinggi pengeluaran pemerintah untuk kesehatan, maka pertumbuhan ekonomi akan mengalami kecenderungan untuk meningkat pula.

\subsection{Pengeluaran Pemerintah di Sektor Infrastruktur}

Infrastruktur menjadi bagian penting dalam peranannya sebagai modal fisik untuk mendukung kelancaran pencapaian tujuan pembangunan, baik di sektor pendidikan, kesehatan maupun kegiatan perekonomian. Penciptaan modal manusia (human capital) pada sektor kesehatan dan pendidikan 
memerlukan sarana infrastruktur seperti gedung sekolah atau gedung pelatihan pendidikan dan kesehatan. Keberadaan sarana infrastruktur jalan maupun sarana transportasi yang memadai, dapat mendukung kelancaran aktivitas perekonomian. Proses distribusi barang dan jasa dari satu daerah menuju daerah lain dapat terselenggara dengan lancar. Kelancaran ini tentunya akan membuat aktivitas perekonomian menjadi kondusif. Mourmouras dan Lee (1999) mengungkapkan bahwa peningkatan pengeluaran infrastruktur mempunyai kecenderungan untuk mendorong terjadinya pertumbuhan ekonomi. ${ }^{5}$ Dengan demikian, ketiga aspek seperti yang telah disebutkan di atas, yakni pendidikan, kesehatan dan infrastruktur secara bersama- sama mempunyai peranan vital dalam rangka mewujudkan tujuan pembangunan, tidak terkecuali pembangunan modal manusia (Todaro dan Smith, 2011).

\subsection{Indeks Pembangunan Manusia (IPM)}

Dalam perkembangannya, gagasan mengenai penggunaan sebuah indeks komposit tunggal muncul setelah UNDP menyiapkan Human Development Report pada 1989. Terdapat beberapa alasan pentingnya penggunaan indeks komposit ini. Pertama, indeks yang baru ini mampu menghitung konsep dasar dari pembangunan manusia dalam rangka memperluas pilihan dalam hidupnya. Pilihan-pilihan ini meliputi keinginan untuk hidup lebih lama, kesempatan untuk mendapatkan pelayanan pendidikan, kesempatan untuk memperoleh kehidupan yang layak serta kesempatan untuk mendapatkan pekerjaan. Kedua, indeks memuat indikator variabel yang terbatas sehingga memudahkan dalam pengaturannya. Ketiga, indeks ini cenderung lebih terkonsep dan tidak sekadar indeks yang terbagi-bagi. Artinya indeks-indeks yang menyusun terbentuknya indeks pembangunan manusia merupakan satu indeks yang mampu menjelaskan satu kesimpulan secara komprehensif. Keempat, indeks pembangunan manusia mengakomodir pilihan-pilihan sosial maupun ekonomi.

\subsection{Penelitian Terdahulu}

Ranis, Stewart dan Ramirez (2000) mengungkapkan bahwa hubungan antara pertumbuhan ekonomi dengan pembangunan manusia terjadi dua arah, yakni bahwa pada satu sisi pembangunan manusia merupakan tujuan utama dari aktivitas manusia dan pertumbuhan ekonomi dianggap sebagai instrumen yang potensial dalam

5 I.A. Mourmouras dan Jong-Eun Lee, "Government Spending on Infrastructure in an Endogenous Growth Model with Finite Horizons", Journal of Economics and Business, 1999, Vol. 1, No. 5. rangka meningkatkan pembangunan manusia, dan pada sisi yang lain, pencapaian tujuan dalam pembangunan manusia mempunyai kontribusi penting dalam rangka meningkatkan pertumbuhan ekonomi.6 Suri, et al (2010) menyebutkan dalam hasil studinya bahwa dalam pengambilan kebijakan hendaknya perlu memberikan perhatian yang lebih intensif kepada program pembangunan manusia, bukan semata-mata karena pembangunan manusia sebagai tujuan utama namun pembangunan manusia juga memberikan kontribusi terhadap peningkatan pertumbuhan ekonomi.

Studi yang dilakukan Ranis dan Stewart (2005) mengungkapkan pentingnya hubungan dua arah antara pertumbuhan ekonomi dan pembangunan manusia sehingga menjadikan keterkaitan ini adalah bersifat hubungan yang saling menguatkan. ${ }^{7}$ Shome dan Tondon (2010) melakukan penelitian mengenai keterkaitan antara pembangunan manusia dengan pertumbuhan ekonomi dengan studi kasus pada 5 negara ASEAN, yaitu Filipina, Singapura, Thailand, Indonesia dan Malaysia. ${ }^{8}$ Hasil penelitian ini memberikan kesimpulan bahwa terdapat korelasi positif antara pertumbuhan ekonomi terhadap Indeks Pembangunan Manusia, namun hanya terjadi pada sebagian negara saja. Ranis (2004) melakukan studi tentang keterkaitan antara pembangunan manusia dan pertumbuhan ekonomi ini berusaha untuk memperluas tujuan pembangunan sekaligus memberi penegasan tentang adanya hubungan timbal balik antara pembangunan manusia dan pertumbuhan ekonomi.

\section{METODOLOGI PENELITIAN}

Penelitian ini bersifat studi deskriptif kuantitatif, dimana suatu permasalahan dicoba untuk dipecahkan melalui tahapan pengumpulan dan penyusunan data-data yang kemudian akan diolah, dianalisis, diinterpretasikan dan disimpulkan agar pihak lain dapat memperoleh gambaran mengenai sifat dan karakteristik (Kuncoro, 2013). Data yang digunakan bersifat data pooling, yaitu

6 Gustav Ranis, Frances Stewart dan Alejandro Ramirez, "Economic Growth and Human Development", World Development, 2000, Vol. 28 No. 2, hlm. 197-219.

7 Gustav Ranis dan Frances Stewart, "Dynamic Links between the Economy and Human Development”, DESA Working Paper, 2005, No. 8.

8 Swaha Shome dan Sarika Tondon, "Balancing Human Development with Economic Growth: A Study of ASEAN 5", Annals of the University of Petrosani, Economics, 2010, Vol.10 (1), hlm. 335348. 
data yang merupakan gabungan antara data time series dan cross section (Kuncoro, 2013).

Penelitian ini menggabungkan data time series selama kurun waktu lima tahun yaitu dari tahun 2009 sampai dengan 2013, dan pengamatan cross section pada 20 provinsi di Indonesia. Teknik yang dipakai dalam pengumpulan data adalah melalui studi pustaka. Studi pustaka merupakan teknik untuk mendapatkan informasi melalui catatan, literatur, dokumentasi dan lain-lain yang masih relevan dengan penelitian ini. Sedangkan teknik pengambilan sampel dalam penelitian ini menggunakan simple random sampling. Simple random sampling adalah cara pengambilan sampel dari anggota populasi tanpa memperhatikan tingkatan dalam anggota populasi tersebut (Riduwan dan Kuncoro, 2014). Dalam kata lain, setiap elemen dari populasi memiliki kesempatan yang sama untuk dipilih (Kuncoro, 2014).

\subsection{Analisis Jalur}

Penelitian ini menggunakan metode analisis jalur dengan tujuan untuk membuktikan dan menganalisis pengaruh variabel eksogen terhadap variabel endogen. Pengaruh tersebut dapat ditunjukkan dengan penggunaan variabel bebas, variabel antara dan variabel terikat. Menurut Riduwan dan Kuncoro (2014), teknik analisis jalur digunakan untuk menguji besarnya kontribusi yang ditunjukkan oleh koefisien jalur pada setiap diagram jalur dari hubungan kausal antar variabel X1, X2, dan X3 terhadap Y serta dampaknya kepada Z. Analisis jalur dapat digunakan untuk menguji persamaan regresi yang melibatkan beberapa variabel eksogen dan variabel endogen sekaligus, sehingga memungkinkan pengujian terhadap variabel antara ${ }^{9}$

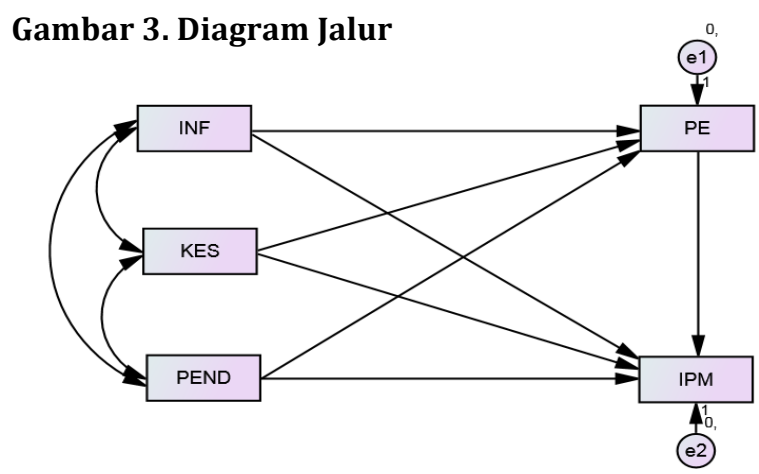

Keterangan:

INF : Pengeluaran Infrastruktur;

KES : Pengeluaran Kesehatan;

PEND : Pengeluaran Pendidikan;

PE : Pertumbuhan Ekonomi;

IPM : Indeks Pembangunan Manusia

\section{HASIL DAN PEMBAHASAN}

Hasil pengujian menggunakan analisis jalur diperoleh hasil sebagai berikut:

\section{Gambar 4. Hasil Analisis Jalur untuk IPM Tinggi}

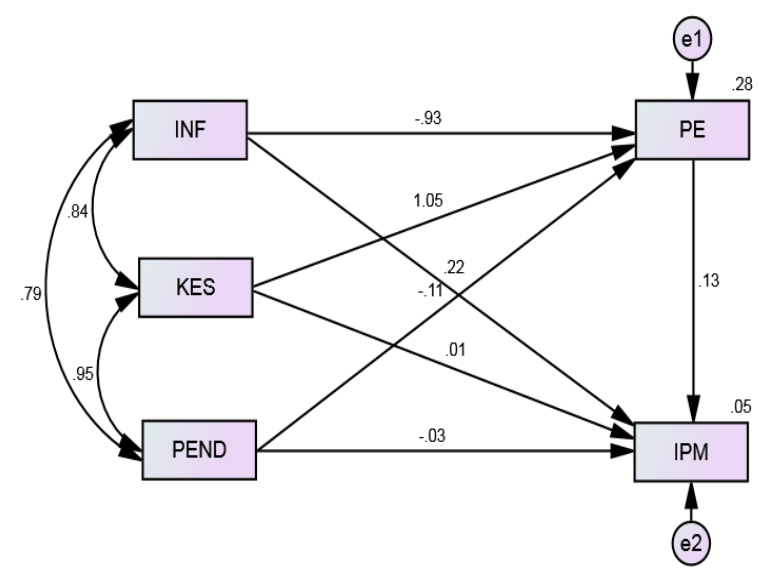

Sumber: Hasil Output IBM SPSS AMOS 21.0

9 Imam Ghozali, Model Persamaan Struktural: Konsep dan Aplikasi dengan Program AMOS 22.0, (Semarang: Badan Penerbit Universitas Diponegoro, 2011). 
Gambar 5. Hasil Analisis Jalur untuk IPM Rendah

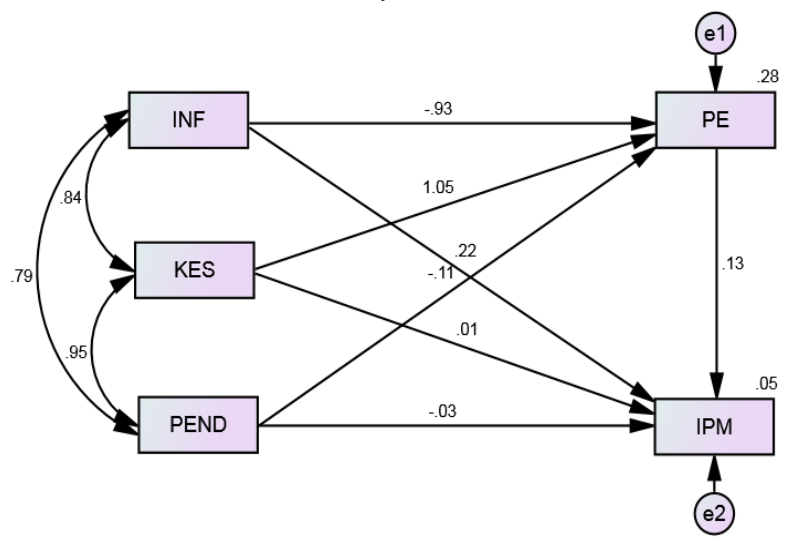

Sumber: Hasil Output IBM SPSS AMOS 21.0

Rangkuman hasil penelitian dapat dilihat pada tabel berikut ini:

Tabel 2. Hubungan antara Variabel Eksogen dan Endogen (IPM Tinggi)

\begin{tabular}{|l|l|l|l|}
\hline \multirow{2}{*}{$\begin{array}{l}\text { Variabel } \\
\text { Eksogen }\end{array}$} & \multicolumn{3}{|c|}{ VEariabel Endogen } \\
\cline { 2 - 4 } & Signifikan & \multicolumn{1}{|c|}{$\begin{array}{l}\text { Tidak } \\
\text { signifikan }\end{array}$} & $\begin{array}{c}\text { IPM } \\
\text { melalui PE }\end{array}$ \\
\hline INF & Signifikikan & $\begin{array}{l}\text { Tidak } \\
\text { signifikan }\end{array}$ & Signifikan \\
\hline KES & $\begin{array}{l}\text { Tidak } \\
\text { signifikan }\end{array}$ & $\begin{array}{l}\text { Tidak } \\
\text { signifikan }\end{array}$ & $\begin{array}{l}\text { Tidak } \\
\text { signifikan }\end{array}$ \\
\hline PEND & - & Signifikan & - \\
\hline PE & - & & \\
\hline
\end{tabular}

Sumber: Output IBM SPSS AMOS 21.0 (data diolah)

Tabel 3. Hubungan antara Variabel Eksogen dan Endogen (IPM Rendah)

\begin{tabular}{|c|c|c|c|}
\hline \multirow[b]{2}{*}{$\begin{array}{l}\text { Variabel } \\
\text { Eksogen }\end{array}$} & \multicolumn{3}{|c|}{ Variabel Endogen } \\
\hline & PE & IPM & $\begin{array}{c}\text { IPM melalui } \\
\text { PE }\end{array}$ \\
\hline INF & $\begin{array}{l}\text { Tidak } \\
\text { signifikan }\end{array}$ & $\begin{array}{l}\text { Tidak } \\
\text { signifikan }\end{array}$ & $\begin{array}{l}\text { Tidak } \\
\text { signifikan }\end{array}$ \\
\hline KES & $\begin{array}{l}\text { Tidak } \\
\text { signifikan }\end{array}$ & $\begin{array}{l}\text { Tidak } \\
\text { signifikan }\end{array}$ & $\begin{array}{l}\text { Tidak } \\
\text { signifikan }\end{array}$ \\
\hline PEND & Signifikan & $\begin{array}{l}\text { Tidak } \\
\text { signifikan }\end{array}$ & Signifikan \\
\hline$\overline{P E}$ & - & Signifikan & - \\
\hline
\end{tabular}

Sumber: Output IBM SPSS AMOS 21.0 (data diolah)

\subsection{Pengaruh Pengeluaran Pemerintah terhadap Pertumbuhan Ekonomi}

Pada daerah dengan IPM yang tergolong tinggi, ditemukan bahwa kontribusi yang relatif besar dalam mendorong pertumbuhan ekonomi terdapat pada pengeluaran di sektor kesehatan dan infrastruktur. Kesimpulan ini sependapat dengan hasil penelitian dari Alexiou (2009) yang menyatakan bahwa pengeluaran pemerintah memberikan kontribusi positif terhadap pertumbuhan ekonomi. Hasil penelitian ini juga menguatkan pendapat Aisa dan Pueyo (2006) yang dalam penelitiannya menyimpulkan bahwa pengeluaran pemerintah untuk kesehatan mempunyai kontribusi positif terhadap harapan hidup dan pertumbuhan ekonomi.

Hasil pengujian tentang pengeluaran pemerintah, memberikan kesimpulan tentang kebenaran teori pertumbuhan ekonomi yang salah satunya mengatakan bahwa pertumbuhan ekonomi merupakan proses kenaikan output dalam jangka panjang (Boediono, 2012). Hal ini dapat ditunjukkan melalui hasil PDRB provinsi yang cenderung mengalami kenaikan setiap tahunnya. Sebagian besar daerah obyek penelitian tercatat mempunyai pencapaian PDRB yang cenderung mengalami peningkatan setiap tahunnya. Hanya provinsi NTB dan Papua yang tercatat mengalami penurunan PDRB, yaitu di provinsi NTB terjadi pada tahun 2011 dan tahun 2012, serta di Papua terjadi pada tahun 2010 dan 2011. Sedangkan laju pertumbuhan PDRB relatif besar tercatat di provinsi Sulawesi Barat dan Papua Barat. Berkaitan dengan pencapaian kualitas manusia yang dideskripsikan dengan angka IPM, hal ini menunjukkan bahwa pertumbuhan ekonomi yang tinggi, yang dilihat dari laju pertumbuhan PDRB, tidak serta merta mencerminkan angka IPM yang tinggi pula.

Sektor kesehatan juga perlu mendapat perhatian guna menciptakan sumber daya yang kompeten untuk ikut andil dalam proses pembangunan mengingat kontribusinya yang relatif besar dalam menggerakkan roda perekonomian dan mendorong pertumbuhan ekonomi. Kesimpulan ini bertolak belakang dengan penelitian yang dilakukan oleh Butkiewicz dan Yanikkaya (2011) yang menyebutkan bahwa pengeluaran total pemerintah mempunyai dampak negatif terhadap pertumbuhan ekonomi. ${ }^{10}$ Untuk dapat menstimulasi terjadinya pertumbuhan ekonomi, beberapa negara berkembang perlu membatasi pengeluaran untuk konsumsi dan lebih banyak melakukan investasi di sektor infrastruktur.

Meluasnya perkembangan wilayah industri dapat menimbulkan adanya eksternalitas, seperti terganggunya sektor pertanian yang memerlukan lahan untuk berproduksi. Studi yang dilakukan oleh Hidayat, Sari dan Aqualdo (2011) menyebutkan bahwa pengeluaran infrastruktur, meskipun menunjukkan adanya hubungan searah yang positif, tidak menunjukkan pengaruh signifikan terhadap

10 James L Butkiewicz dan Halit Yanikkaya, "Institutions and the Impact of Government Spending on Growth", Journal of Applied Economics, 2011, Vol. XIV, No. 2, hlm. 319-341. 
pertumbuhan ekonomi.11 Hal yang kontras diungkapkan oleh Prasetyo dan Firdaus (2011) yang menyimpulkan bahwa pengeluaran infrastruktur, baik itu berupa listrik, jalan maupun air bersih, menunjukkan pengaruh yang positif dan signifikan terhadap pertumbuhan ekonomi. Baldacci, et al. (2008) mengungkapkan bahwa pengeluaran pemerintah di sektor kesehatan dan pendidikan pada akhirnya dapat mendongkrak pertumbuhan ekonomi. ${ }^{12}$ Namun pengeluaran pemerintah sendiri tidak cukup mendorong terjadinya pertumbuhan ekonomi. Keberhasilan tersebut perlu didukung dengan kebijakan pemerintah yang terkait dengan pelaksanaan pengeluaran pemerintah, seperti misalnya kebijakan penekanan laju inflasi. Hal ini juga sependapat dengan Butkiewicz dan Yanikkaya (2011) yang dalam penelitiannya menyimpulkan bahwa kebijakan pemerintah, terutama kebijakan fiskal, mempunyai peran utama dalam menentukan terjadinya pertumbuhan ekonomi. ${ }^{13}$

\subsection{Pengaruh Pertumbuhan Ekonomi terhadap Indeks Pembangunan Manusia}

Suatu daerah dikatakan berada dalam kondisi pertumbuhan ekonomi apabila terlihat proses kenaikan output dalam jangka panjang (Boediono, 2012). ${ }^{14}$ Hasil dalam penelitian ini mengungkapkan bahwa pertumbuhan ekonomi terlihat memberikan sinyal adanya trickle down effect pada perkembangan IPM. Hal ini dapat terlihat pada daerah dengan angka IPM tinggi maupun pada daerah dengan angka IPM rendah. Selain menunjukkan eksistensi trickle down effect, penelitian ini juga mendukung penelitian yang dilakukan Subagyo dan Algifari (2013) tentang kausalitas pembangunan manusia dan pertumbuhan ekonomi di lingkup Jawa dan Bali yang menyimpulkan bahwa pertumbuhan ekonomi berpengaruh terhadap angka IPM.

Selama lima tahun masa observasi, daerah obyek penelitian menunjukkan angka IPM yang cenderung mengalami kenaikan dibandingkan tahun sebelumnya. Untuk lebih jelasnya dapat dilihat pada gambar berikut:

11 Muhammad Hidayat, Lapeti Sari dan Nobel Aqualdo, "Analisis Faktor-faktor yang Mempengaruhi Pertumbuhan Ekonomi Kota Pekanbaru", Jurnal Sosial Ekonomi Pembangunan, 2011, Vol. II, No.4.

12 E. Baldacci, et al, "Social Spending, Human Capital, and Growth in Developing Countries", World Development, 2008, Vol. 36, No. 8, hlm. 1317-1341.

13 James L Butkiewicz dan Halit Yanikkaya, Op.Cit.

\section{Gambar 6. Perkembangan Indeks Pembangunan} Manusia

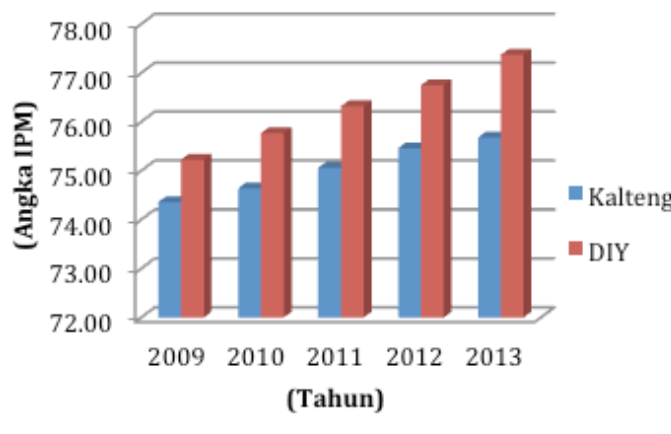

Sumber: BPS, 2015 (data diolah)

Sesuai dengan gambar diatas, terlihat bahwa provinsi Kalimantan Tengah dan DIY yang mewakili dari sebagian besar daerah yang menjadi obyek penelitian menunjukkan angka IPM yang cenderung meningkat dari tahun ke tahun. Hal ini diikuti dengan kecenderungan meningkatnya pertumbuhan ekonomi daerah. Fenomena ini terlihat pada daerah yang tergolong sebagai daerah dengan IPM tinggi dan juga pada daerah dengan angka IPM rendah, seperti terlihat pada gambar berikut:

\section{Gambar 7. Grafik Pertumbuhan Ekonomi}

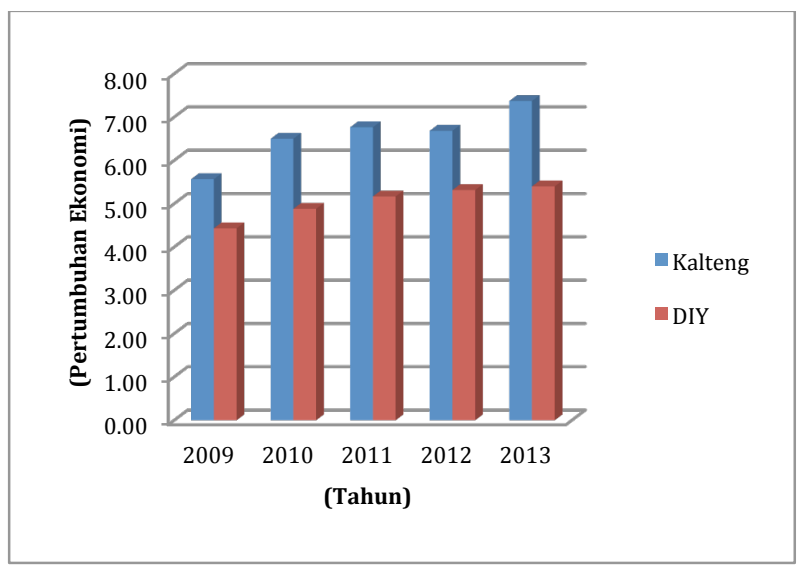

Sumber: BPS, 2015 (data diolah)

Kesimpulan yang dapat diambil dari fenomena di atas adalah bahwa pertumbuhan ekonomi mempunyai kontribusi yang besar dalam menaikkan angka IPM pada sebagian besar daerah di Indonesia. Hal ini juga memperkuat eksistensi trickle down effect yang ditimbulkan dari pertumbuhan ekonomi terhadap angka IPM yang didalamnya terdiri dari komponen- komponen seperti angka harapan hidup, angka melek huruf dan rata- rata lama sekolah dan pengeluaran riil perkapita yang disesuaikan (purchasing power parity).

14 Boediono, Op.Cit. 


\subsection{Pengaruh Pengeluaran Pemerintah terhadap Indeks Pembangunan Manusia melalui Pertumbuhan Ekonomi}

Pada kelompok daerah dengan angka IPM tinggi, kontribusi positif ditunjukkan melalui pengeluaran di sektor kesehatan dan infrastruktur dengan kontribusi yang relatif besar dibandingkan dengan jenis pengeluaran lainnya. Sedangkan pada kelompok daerah dengan angka IPM rendah, kontribusi positif ditunjukkan melalui pengeluaran pendidikan yang relatif lebih besar dibandingkan jenis pengeluaran lainnya, yakni pengeluaran infrastruktur ataupun pengeluaran kesehatan. Hal ini sependapat dengan Sasana (2012) yang mengemukakan bahwa pengeluaran pemerintah mempunyai pengaruh terhadap IPM melalui peningkatan kualitas sarana dan prasarana umum atau program-program langsung yang dapat merangsang produktivitas yang lebih besar bagi masyarakat serta pelaku usaha di daerah. Namun, hal ini berbeda dengan hasil penelitian Sumiyati (2008) yang menyebutkan bahwa belanja atau pengeluaran yang dilakukan pemerintah tidak mempunyai pengaruh yang signifikan terhadap IPM. Badrudin dan Khasanah (2011) juga mengungkapkan hal yang sama yang dalam penelitiannya menunjukkan bahwa belanja daerah yang diproksikan dengan alokasi belanja di sektor pendidikan, kesehatan dan infrastruktur mempunyai pengaruh yang tidak signifikan terhadap pembangunan manusia yang diproksikan kedalam IPM. ${ }^{15}$

Penelitian yang dilakukan oleh Lubis (2013) mengemukakan bahwa pengeluaran di sektor pendidikan dan kesehatan dapat meningkatkan kualitas sumber daya manusia melalui konsumsi nutrisi yang baik, partisipasi pendidikan, dan kemudahan akses terhadap kesehatan sehingga setiap individu mempunyai ketahanan fisik, kemampuan, pengetahuan, dan keterampilan sebagai modal dasar manusia (human capital). Hal ini juga menguatkan pendapat Asri, Nikensari dan Kuncara (2013) yang dalam penelitiannya mengungkapkan bahwa pengeluaran pemerintah khususnya pada sektor pendidikan mempunyai kontribusi yang relatif besar terhadap angka IPM.16

15 Rudy Badrudin dan Mufidhatul Khasanah, "Pengaruh Pendapatan dan Belanja Daerah Terhadap Pembangunan Manusia di Provinsi Daerah Istimewa Yogyakarta", Buletin Ekonomi, Jurnal Manajemen, Akuntansi dan Ekonomi Pembangunan, 2011, Vol. 9, No. 1, hlm. 23-30.

16

Meylina Astri, Sri Indah Nikensari dan Harya Kuncara W, "Pengaruh Pengeluaran Pemerintah Daerah Pada Sektor Pendidikan dan Kesehatan Terhadap Indeks Pembangunan Manusia di

\section{KESIMPULAN DAN SARAN}

\subsection{Kesimpulan}

Penelitian ini mengungkapkan beberapa kesimpulan yaitu, pertama, bahwa pengeluaran pemerintah mempunyai kontribusi positif dalam menciptakan pertumbuhan ekonomi. Akan tetapi, terdapat pola yang berbeda diantara dua obyek penelitian, dimana pada kelompok daerah dengan angka IPM tinggi menunjukkan bahwa pengeluaran kesehatan dan infrastruktur memiliki kontribusi yang relatif lebih besar dibandingkan dengan pengeluaran lainnya dalam mendorong pertumbuhan ekonomi. Adapun pada kelompok daerah dengan angka IPM rendah mengindikasikan bahwa pengeluaran pendidikan mempunyai kontribusi yang relatif lebih besar dibandingkan pengeluaran lainnya dalam mendorong pertumbuhan ekonomi. Kedua, pertumbuhan ekonomi mempunyai kontribusi yang relatif besar dalam menentukan angka IPM. Hal ini terjadi pada baik kelompok daerah dengan angka IPM tinggi maupun kelompok daerah dengan angka IPM rendah. Kesimpulan ini juga memperkuat pendapat tentang adanya trickle down effect pertumbuhan ekonomi terhadap IPM. Terakhir, pengeluaran pemerintah mempunyai kontribusi positif secara tidak langsung dalam mendorong meningkatnya IPM. Hal ini dapat terjadi melalui pertumbuhan ekonomi sebagai komponen perantaranya. Namun terdapat perbedaan perilaku antara kelompok daerah dengan angka IPM tinggi dengan kelompok daerah dengan angka IPM rendah. Pada kelompok daerah dengan angka IPM tinggi, pengeluaran kesehatan dan infrastruktur terlihat mempunyai kontribusi tidak langsung yang relatif besar terhadap angka IPM melalui pertumbuhan ekonomi. Sedangkan pada kelompok daerah dengan angka IPM rendah terlihat bahwa pengeluaran pendidikan mempunyai kontribusi secara tidak langsung dalam menentukan angka IPM melalui pertumbuhan ekonomi.

\subsection{Saran}

Sesuai dengan kesimpulan yang telah disebutkan di atas, dapat diajukan saran sebagai berikut:

\subsubsection{Pengeluaran pemerintah mempunyai kontribusi secara langsung terhadap pertumbuhan ekonomi dan kontribusi secara tidak langsung terhadap Indeks Pembangunan Manusia (IPM). Namun, tidak semua jenis}

Indonesia”, Jurnal Pendidikan Ekonomi dan Bisnis, 2013, Vol. 1, No. 1. 
pengeluaran memberikan kontribusi yang sama. Untuk itu, kelompok daerah dengan angka IPM rendah perlu memaksimalkan pengeluarannya, terutama pada pengeluaran yang terindikasi mempunyai kontribusi positif, seperti pada pengeluaran pendidikan. Sedangkan untuk daerah dengan angka IPM tinggi, perlu memperhatikan pengeluarannya di sektor kesehatan, seperti misalnya:

a. Untuk daerah dengan IPM tinggi, dimana pengeluaran kesehatan mempunyai peranan yang vital, maka pemerintah dapat mengoptimalkan pemberian Bantuan Operasional Kesehatan (BOK);

b. Untuk daerah dengan IPM rendah, dimana pengeluaran pendidikan mempunyai peranan yang lebih penting, maka pemerintah dapat mengoptimalkan pemberian Bantuan Operasional Pendidikan (BOP).

5.2.2 Pertumbuhan ekonomi merupakan sebuah instrument penting yang dapat digunakan untuk melihat kondisi perekonomian suatu daerah. Meskipun tidak bersifat mutlak, namun pertumbuhan ekonomi mampu menjadi tolok ukur untuk mengetahui kondisi perekonomian, apakah sehat atau tidak. Untuk itu, pemerintah, baik pada kelompok daerah IPM tinggi maupun kelompok daerah IPM rendah perlu menjaga stabilitas pertumbuhan ekonomi. Alternatif yang dapat dilakukan antara lain:

a. Meningkatkan arus investasi daerah, baik dari dalam maupun luar negeri dengan melakukan promosi investasi serta menyelenggarakan reformasi birokrasi terkait dengan pengurusan administrasinya;

b. Membangun sarana infrastruktur yang dapat menunjang aktivitas ekonomi, seperti pembangunan jalan, jembatan dan pelabuhan;

c. Menciptakan lapangan kerja bagi masyarakat lokal;

d. Untuk menjaga daya beli masyarakat, pemerintah daerah perlu menjaga tingkat inflasi daerah.

5.2.3 Pengeluaran pemerintah mempunyai kontribusi tidak langsung terhadap capaian angka indeks pembangunan manusia (IPM) melalui pertumbuhan ekonomi. Akan tetapi terdapat respon yang berbeda antara dua kelompok daerah dalam memberikan kontribusi peningkatan angka IPM, dimana pada kelompok daerah dengan IPM tinggi menunjukkan bahwa yang memiliki kontribusi secara tidak langsung terhadap IPM adalah pengeluaran kesehatan dan infrastruktur, sedangkan pada kelompok daerah dengan IPM rendah menunjukkan bahwa yang memiliki kontribusi secara tidak langsung terhadap IPM adalah pengeluaran pendidikan. Pendidikan dan kesehatan merupakan bagian fundamental dari pembangunan manusia. Hal ini dapat ditempuh dengan salah satu caranya yaitu pengelolaan terhadap human capital. Untuk itu, baik kelompok daerah IPM tinggi maupun kelompok daerah IPM rendah sama-sama perlu melakukan optimalisasi pengeluarannya untuk mendorong pertumbuhan ekonomi pada umumnya dan memperbaiki angka IPM pada khususnya. Pembentukan human capital dapat dilakukan dengan cara penyelenggaraan program pendidikan dan pelatihan serta penyediaan fasilitas-fasilitas publik yang memadai sehingga masyarakat dapat dengan mudah memperoleh akses pelayanan publik. Untuk daerah dengan IPM tinggi, pemerintah dapat memberikan prioritas pengeluaran kesehatan, sedangkan untuk daerah dengan IPM rendah maka pemerintah dapat mengoptimalkan pengeluaran pendidikan. Untuk mendukung hal ini, pemerintah dapat melakukan investasi yang lebih besar pada sektor pendidikan dan kesehatan.

\section{IMPLIKASI DAN KETERBATASAN}

Penelitian ini mempunyai implikasi terhadap pengambilan kebijakan yang diambil terkait dengan kondisi yang ditemui di lapangan sebagaimana disebutkan dalam hasil penelitian. Implikasi kebijakan yang dimaksud adalah berkaitan dengan perbaikan pengelolaan pemerintah dalam hubungannya dengan pertumbuhan ekonomi dan indeks pembangunan manusia. Pada intinya, pemerintah daerah perlu mengoptimalkan pengeluarannya, khususnya pada pengeluaran pendidikan, kesehatan dan infrastruktur untuk meningkatkan pertumbuhan ekonomi yang pada akhirnya berimplikasi pada peningkatan indeks pembangunan manusia.

Penelitian ini mempunyai beberapa keterbatasan sehingga berpotensi untuk dilakukan pengembangan pada penelitian berikutnya, antara lain:

6.1 Penelitian ini menggunakan sampel yang relatif sedikit untuk mewakili kelompok daerah yang mempunyai angka IPM tinggi dan kelompok daerah dengan angka IPM rendah. Dengan demikian, penelitian selanjutnya dapat 
menggunakan sampel yang lebih luas untuk memperkuat daya generalisasi.

6.2 Penelitian ini menggunakan periode tahun yang relatif cukup singkat, yaitu 5 tahun, sehingga untuk keperluan kolektivitas data yang lebih banyak maka dalam penelitian selanjutnya dimungkinkan untuk menambah masa periode observasi.

6.3 Penelitian ini menggunakan 3 jenis pengeluaran pemerintah, yakni pengeluaran kesehatan, pendidikan dan infrastruktur yang dikaitkan dengan pertumbuhan ekonomi dan indeks pembangunan manusia. Mengingat pengeluaran pemerintah dibagi ke dalam beberapa bidang, maka terbuka kemungkinan untuk dilakukan penelitian berikutnya guna mengetahui lebih lanjut variabel pengeluaran apa yang paling dominan memberikan kontribusi dalam meningkatkan pertumbuhan ekonomi dan indeks pembangunan manusia.

\section{PENGHARGAAN (ACKNOWLEDGEMENT)}

Kami mengucapkan terima kasih kepada berbagai pihak yang telah mendukung dan memberikan kontribusi sehingga penelitian ini dapat terselesaikan. Bersama ini pula kami menyampaikan bahwa penelitian ini tidak terlepas dari kemungkinan eror, dan hal tersebut menjadi tanggung jawab penulis. Ucapan terima kasih khusus kami sampaikan kepada Dewan Redaksi Indonesian Treasury Review yang memungkinkan karya tulis ilmiah ini dapat diterbitkan.

\section{DAFTAR PUSTAKA}

Arsyad, Lincolin. (2006). Ekonomi Pembangunan. Erlangga. Jakarta.

Astri, Meylina, Sri Indah Nikensari dan Harya Kuncara W. (2013). "Pengaruh Pengeluaran Pemerintah Daerah Pada Sektor Pendidikan dan Kesehatan Terhadap Indeks Pembangunan Manusia di Indonesia", Jurnal Pendidikan Ekonomi dan Bisnis, Vol. 1 No. 1. Maret 2013.

Badan Pusat Statistik. (2014). Statistik Indonesia 2014. Jakarta: Badan Pusat Statistik.

Badrudin, Rudy dan Mufidhatul Khasanah. (2011). "Pengaruh Pendapatan dan Belanja Daerah Terhadap Pembangunan Manusia di Provinsi Daerah Istimewa Yogyakarta", Buletin Ekonomi, Jurnal Manajemen, Akuntansi dan Ekonomi Pembangunan, Vol. 9, No. 1. April 2009: 23-30.

Baldacci, E. et al. (2008). "Social Spending, Human Capital, and Growth in Developing Countries",
World Development. Vol. 36, No. 8, hlm. 13171341.

Barro, R. (2013). "Education and Economic Growth", Annals of Economic and Finance. Vol. 14-2 (A), hlm. 277-304.

Benos, Nikos dan Stefania Zotou. (2014). "Education and Economic Growth: A Meta-regression Analysis", World Development, Vol. 64, hlm. 669-689.

Boediono. (2012). Teori Pertumbuhan Ekonomi, Edisi Pertama. Yogyakarta: BPFE.

Butkiewicz, James L. dan Halit Yanikkaya. (2011). "Institutions and the impact of government spending on growth", Journal of Applied Economics. Vol. XIV, No. 2, hlm. 319-341.

Christy, Fhino Andrea dan Priyo Hari Adi. (2009). "Hubungan antara Dana Alokasi Umum, Belanja Modal dan Kualitas Pembangunan Manusia", The $3^{\text {rd }}$ National Conference UKWMS.

Garson, G. David. (2012). Testing Statistical Assumptions. Statistical Associates Publishing,

Ghozali, Imam. (2011). Model Persamaan Struktural: Konsep dan Aplikasi dengan Program AMOS 22.0. Semarang: Badan Penerbit Universitas Diponegoro.

Haryanto, Tommy Prio. (2013). "Pengaruh Pengeluaran Pemerintah Terhadap Pertumbuhan Ekonomi Kabupaten/ Kota di Provinsi Jawa Tengah Tahun 2007-2011", Economics Development Analysis Journal, Vol. 2 (3).

Harttgen, Kenneth dan Stephan Klasen. (2011). "A Household-Based Human Development Index", World Development, Vol. 40, No. 5, hlm. 878899.

Hayek, F. A. (1945). "The Use of Knowledge in Society", American Economic Review, Vol. XXXV, hlm. 519-530.

Hidayat, Muhammad, Sari Lapeti dan Aqualdo, Nobel. (2011). "Analisis Faktor-faktor yang Mempengaruhi Pertumbuhan Ekonomi Kota Pekanbaru", Jurnal Sosial Ekonomi Pembangunan, Vol. II, No.4.

Hyman, David N. (2004). Public Finance: A Contemporary Application of Theory to Policy, Eight Edition. South-Western.

Jhingan, M.L. (1992). Ekonomi Pembangunan dan Perencanaan. Jakarta: Rajawali.

Kementerian Pekerjaan Umum. (2013). Buku Informasi Statistik Pekerjaan Umum 2013. Jakarta: Pusdata Kementerian Pekerjaan Umum. 
Kuncoro, Mudrajad. (2006). Ekonomika Pembangunan: Teori, Masalah dan Kebijakan, Edisi Keempat. Yogyakarta: UPP STIM YKPN.

Kuncoro, Mudrajad. (2013). Metode Riset untuk Bisnis \& Ekonomi. Edisi Keempat. Jakarta: Erlangga.

Legowo, P.S. (2009). "Dampak Keterkaitan Infrastruktur Jaringan Jalan terhadap Pertumbuhan Sektoral Wilayah di Jabodetabek", Simposium XII FSTPT, Universitas Kristen Petra Surabaya. 14 November 2009.

Mangkoesoebroto, Guritno. (2013). Ekonomi Publik, Edisi Ketiga. Yogyakarta: BPFE.

Melliana, Ayunanda dan Ismaini Zain. (2013). "Analisis Statistika Faktor yang Mempengaruhi Indeks Pembangunan Manusia di Kabupaten/ Kota Provinsi Jawa Timur dengan Menggunakan Regresi Panel", Jurnal Sains dan Seni Pomits. Vol. 2, No. 2, hlm. 237-242.

Mirza, Denni Sulistio. (2012). "Pengaruh Kemiskinan, Pertumbuhan Ekonomi dan Belanja Modal Terhadap Indeks Pembangunan Manusia di Jawa Tengah Tahun 2006-2009", Economic Development Analysis Journal, Vol. 1, No.1.

Mourmouras, I.A., dan Jong-Eun Lee. (1999). "Government Spending on Infrastructure in an Endogenous Growth Model with Finite Horizons", Journal of Economics and Business. Vol. 1, No. 5.

Prasetyo, Ahmad Danu dan Ubaidillah Zuhdi. (2013). "The Government Expenxiture Efficiency towards the Human Development", International Conference on Applied Economic (ICOAE) 2013, Procedia Economic and Finance, Vol. 5, hlm. 615-622.

Prasetyo, Rindang Bangun dan Firdaus, Muhammad. (2009). "Pengaruh Infrastruktur pada Pertumbuhan Ekonomi Wilayah di Indonesia", Jurnal Ekonomi dan Kebijakan Pembangunan. Vol. 2(2), hlm. 222-236.

Putra, I Gede Dwi Purnama dan I Made Adigorim. (2012). "Pengaruh Belanja Langsung dan Belanja Tidak Langsung Terhadap Pertumbuhan Ekonomi", E-Jurnal Ekonomi Pembangunan Universitas Udayana, Vol. 1 No. 2, hlm. 61-120.

Ranis, Gustav dan Frances Stewart. (2005). "Dynamic Links between the Economy and Human Development", DESA Working Paper, No. 8.

Ranis, Gustav, Frances Stewart dan Alejandro Ramirez. (2000). "Economic Growth and
Human Development. World Development, Vol. 28 No. 2, hlm. 197-219.

Peraturan Menteri Dalam Negeri No. 13 Tahun 2006 tentang Pedoman Pengelolaan Keuangan Daerah.

Peraturan Menteri Dalam Negeri No. 21 Tahun 2011 tentang Perubahan Kedua Atas Peraturan Menteri Dalam Negeri No. 13 Tahun 2006 tentang Pedoman Pengelolaan Keuangan Daerah.

Setyowati, Lilis dan Yohana Kus Suparwati. (2012). "Pengaruh Pertumbuhan Ekonomi, DAU, DAK, PAD Terhadap Indeks Pembangunan Manusia dengan Pengalokasian Anggaran Belanja Modal Sebagai Variabel Intervening (Studi Empiris Pada Pemerintah Kabupaten dan Kota Se-Jawa Tengah)", Prestasi, Vol. 9 No. 1.

Shome, Swaha dan Sarika Tondon. (2010). "Balancing Human Development with Economic Growth: A Study of ASEAN 5", Annals of the University of Petrosani, Economics, Vol. 10(1), hlm. 335-348.

Tiebout, Charles M. (1956). "A Pure Theory of Local Expenditure", Journal of Political Economy. Vol.64, No. 5, hlm. 416-424.

Todaro, Michael P. (2000). Pembangunan Ekonomi di Dunia Ketiga, Edisi Ketujuh. Jakarta: Erlangga.

Todaro, Michael P dan Stephen C. Smith. (2011). Pembangunan Ekonomi di Dunia Ketiga, Edisi Kesebelas, Jilid I. Jakarta: Erlangga

Trihendradi, C. (2013). Step by Step IBM SPSS 21: Analisis Data Statistik. Yogyakarta: Andy Offset.

Ul Haq, Mahbub. (1995). Reflections on Human Development. Oxford University Press.

Universitas Brawijaya. (2009). Modul Pelatihan SEM (Structural Equations Modeling) 2009. Malang: Fakultas Ekonomi Universitas Brawijaya.

Vegirawati, Titin. (2012). "Pengaruh Alokasi Belanja Langsung Terhadap Kualitas Pembangunan Manusia (Studi Kasus Pada Pemerintah Kabupaten Kota di Sumatera Selatan)", Jurnal Ekonomi dan Informasi Akuntansi, Vol. 2, No. 1.

Welzel, C., Inglehard, R., dan Klingemann, HansDieter. (2003). "The Theory of Human Development: A Cross-cultural Analysis", European Journal of Political Research. Vol 42, hlm. 341-379.

http://www.djpk.kemenkeu.go.id/ diakses pada tanggal 1 Desember 2014. 